\title{
PENGARUH UKURAN PERUSAHAAN, LABA RUGI OPERASI, SOLVABILITAS, UMUR PERUSAHAAN, KLASIFIKASI INDUSTRI, DAN UKURAN KAP TERHADAP AUDIT DELAY
}

(Studi pada Perusahaan Indeks Kompas 100 Periode 2012-2014)

\author{
Charviena \\ Universitas Multimedia Nusantara \\ charviena@hotmail.com \\ Elisa Tjhoa \\ Universitas Multimedia Nusantara \\ elisa.tjhoa@umn.ac.id
}

\section{Abstract}

The objective of this study was to obtain empirical evidence about the effect of company size, profit or loss, solvability, age of company, classification of industry, and public accounting firm size towards audit delay. In this study, company size was measured by log total asset, profit or loss measured by company's operational profit or loss, solvability measured by total debt to total asset (TDTA) ratio, age of company measured since company establishment year until year of financial statement, classification of industry measured by non financial or financial industry, public accounting firm size measured by big four or non-big four.

The object of this study was the company listed in Indeks Kompas 100 between 20122014, sample was selected with purposive sampling, and the statistic method used in this study was multiple regression.

The result of this study was profit or loss, solvability, age of company, classification of industry, and public accounting firm size had no effect towards audit delay, while company size had significant effect towards audit delay. All independent variables had significant effect towards audit delay simultaneously.

Keywords : Audit Delay, Classification of Industry, Company Age, Company Size, Profit or loss, Public Accounting Firm Size, Solvability.

\section{Pendahuluan}

Bisnis dan ekonomi di Asia Tenggara berkembang semakin kompleks. Hal ini ditandai dengan dibentuknya kerjasama ASEAN Economy Community (AEC) oleh negara anggota Association of South East Asian Nation (ASEAN) pada tahun 2015. Akibatnya, untuk mengantisipasi AEC agar tidak kalah bersaing dengan perusahaan asing khususnya terkait permodalan, semakin banyak perusahaan yang berusaha listing di Bursa Efek Indonesia (BEI). Permodalan merupakan faktor penting bagi kelangsungan hidup suatu bisnis, hal tersebut terbukti dengan adanya peningkatan jumlah perusahaan yang tercatat di BEI.

Dengan adanya kerjasama AEC membuka peluang bagi perusahaan untuk mendapatkan dana baik dari investor dalam negeri maupun investor luar negeri dengan lebih bebas serta mudah, sehingga perusahaan perlu meningkatkan nilai dan reputasinya agar para investor tertarik untuk melakukan penanaman modal. Laporan keuangan merupakan salah satu media yang dapat digunakan untuk melihat kinerja dari sebuah perusahaan. Para investor tentunya akan lebih tertarik dengan kinerja perusahaan yang baik. 
Otoritas Jasa Keuangan (OJK) sebagai regulator pasar modal mewajibkan setiap perusahaan yang terdaftar di Bursa Efek Indonesia untuk menyampaikan laporan keuangan secara berkala selambat-lambatnya tiga bulan setelah tanggal laporan keuangan tahunan. Hal ini diatur dalam peraturan OJK Nomor X.K.2, tentang Kewajiban Penyampaian Laporan Keuangan Berkala. Laporan keuangan bertujuan untuk memberikan informasi tentang posisi keuangan, kinerja dan arus kas perusahaan yang bermanfaat bagi sebagian besar pemakai laporan keuangan dalam rangka pengambilan keputusan ekonomi serta menunjukkan tanggung jawab manajemen dalam penggunaan sumber daya perusahaan (Ikatan Akutan Indonesia, 2014). Keterlambatan penyampaian laporan keuangan perusahaan kepada publik berdampak pada pengenaan sanksi bagi perseroan. Selama ini, untuk menimbulkan efek jera bagi emiten yang terlambat menyerahkan laporan keuangannya, BEI mengenakan sanksi secara berjenjang bahkan suspensi efek.

Ketepatan waktu auditor dalam menyelesaikan laporan audit akan mempengaruhi ketepatwaktuan publikasi kepada masyarakat dan Otoritas Jasa Keuangan (OJK). Lamanya waktu (jumlah hari) dari tanggal tutup buku sampai dengan tanggal yang tertera pada laporan audit disebut audit delay. Dalam penelitian-penelitian lain, audit delay disebut juga dengan istilah audit report lag (Lianto dan Kusuma, 2010). Tanggal selesainya pekerjaan lapangan harus digunakan sebagai tanggal laporan auditor independen (SPAP SA Seksi 530, 2011).

Dyer dan McHugh (1975) dalam Arungningrum dan Wirakusuma (2013) mengatakan audit delay adalah interval waktu antara tahun tutup buku laporan keuangan hingga opini pada laporan keuangan audit ditandatangani. Panjangnya masa audit delay ini berbanding lurus dengan lamanya masa pekerjaan lapangan diselesaikan auditor sehingga semakin lama pekerjaan lapangan maka semakin lama audit delay yang terjadi. Apabila laporan keuangan disajikan terlambat maka informasi yang terkandung di dalamnya menjadi tidak relevan dalam pengambilan keputusan.

Ukuran perusahaan merupakan salah satu faktor yang berpengaruh terhadap audit delay (Martia dan Hidayati, 2013). Ukuran perusahaan menggambarkan besar kecilnya suatu perusahaan yang salah satunya ditunjukkan oleh besarnya aset yang dimiliki oleh perusahaan. Perusahaan besar pada umumnya akan menyelesaikan proses audit lebih cepat dibandingkan dengan perusahaan kecil dikarenakan adanya internal control yang baik dan kemampuan perusahaan untuk mendorong auditornya untuk menyelesaikan pekerjaan audit secara tepat waktu (Iskandar dan Trisnawati, 2010). Perusahaan besar cenderung memiliki lebih banyak staff akuntansi dan sistem pencatatan yang lebih baik sehingga dapat mempersiapkan dokumen yang dibutuhkan oleh auditor serta memperkecil kemungkinan keslahan pencatatan sehingga jangka waktu audit menjadi lebih pendek dan audit delay berkurang. Namun, menurut Eka (2014), perusahaan yang memiliki total aset yang besar akan memerlukan waktu yang lebih panjang dalam proses audit dikarenakan semakin banyak informasi dan semakin luas lingkup audit sehingga prosedur audit akan lebih banyak. Penelitian oleh Febrianty (2011) menyatakan bahwa ukuran perusahaan berpengaruh signifikan terhadap audit delay. Sementara penelitian Aditya dan Anisyukurlillah (2014) memperoleh hasil bahwa ukuran perusahaan tidak berpengaruh terhadap audit delay karena semua perusahaan akan berusaha untuk lebih cepat mempublikasikan laporan keuangannya guna menarik perhatian dari investor dan menghindari sanksi yang diberlakukan.

Laba rugi dapat digunakan sebagai salah satu alat ukur kinerja perusahaan. Laba merupakan selisih lebih total pendapatan dikurangi dengan total bebannya, disebut juga pendapatan bersih atau net earnings (Horngren, 2015). Laba rugi yang digunakan dalam penelitian ini adalah laba operasi atau rugi operasi, karena laba operasi dianggap lebih mampu menggambarkan kegiatan operasional perusahaan. Menurut Givoly dan Palmon (1982) dalam Puspitasari dan Sari (2012), ketepatan waktu bergantung pada lamanya waktu audit dan ketepatan waktu pengumuman laba rugi tahunan dipengaruhi oleh isi laporan keuangan. 
Subekti dan Widiyanti (2004) dalam Iskandar dan Trisnawati (2010) menyatakan ada beberapa alasan terjadinya kemunduran laporan publikasi, yaitu pelaporan laba rugi sebagai indikator good news atau bad news atas kinerja manajerial perusahaan dalam setahun. Ketika perusahaan memperoleh good news, kecenderungan yang terjadi adalah perusahaan akan menginformasikannya kepda publik dan dengan demikian audit delay akan berkurang. Sementara ketika perusahaan memperoleh rugi dari hasil operasionalnya, maka perusahaan akan berusaha menahan pengumuman bad news kepada masyarakat terutama kepada investor. Menurut Eka (2014), ketika kerugian terjadi perusahaan ingin menunda berita buruk tersebut dengan meminta auditor untuk menjadwal ulang penugasan audit dan auditor akan lebih berhati-hati selama proses audit jika percaya bahwa kerugian ini mungkin disebabkan karena kegagalan perusahaan atau kecurangan manajemen. Kehati-hatian auditor dalam proses audit dapat dilakukan dengan penambahan prosedur audit yang dilakukan sehingga dapat memperpanjang masa audit. Dengan demikian dapat disimpulkan bahwa laba rugi dari perusahaan berpengaruh terhadap audit delay. Penelitian yang dilakukan oleh Iskandar dan Trisnawati (2010) menunjukkan bahwa laba rugi perusahaan berpengaruh signifikan terhadap audit delay. Sementara penelitian yang dilakukan Kartika (2011) menyatakan bahwa tidak ada pengaruh laba rugi terhadap audit delay.

Solvabilitas merupakan rasio yang mengukur kemampuan perusahaan dalam melunasi seluruh kewajibannya dengan aset yang dimiliki. Dalam penelitian ini, solvabilitas diproksikan dengan menggunakan Total Debt to Total Asset Ratio (TDTA). Perusahaan yang tidak solvable adalah perusahaan yang proporsi utangnya lebih besar dibandingkan total asetnya (Puspitasari dan Sari, 2012). Proporsi yang tinggi dari utang terhadap total aset akan mempengaruhi likuiditas yang terkait dengan masalah kelangsungan hidup perusahaan sehingga memerlukan kecermatan yang lebih dalam pengauditan (Rachmawati dalam Lianto dan Kusuma, 2010). Perusahaan dengan tingkat utang yang tinggi juga memiliki resiko gagal bayar yang tinggi sehingga meningkatkan kehati-hatian auditor dalam melakukan audit. Ketika melakukan proses audit atas utang, auditor akan berupaya untuk mencari bukti-bukti pendukung atas dokumen utang dan kepemilikan aset perusahaan. Jadi, semakin tinggi rasio utang terhadap total aset, semakin lama rentang waktu yang dibutuhkan untuk penyelesaian audit laporan keuangan tahunan, sehingga dapat disimpulkan bahwa solvabilitas berpengaruh terhadap audit delay. Hal tersebut didukung oleh hasil penelitian Laksono (2014) yang menyatakan bahwa solvabilitas berpengaruh signifikan terhadap audit delay. Sebaliknya, hasil penelitian Iskandar dan Trisnawati (2010) menyatakan bahwa solvabilitas tidak berpengaruh terhadap audit delay.

Faktor lainnya yang dapat mempengaruhi audit delay adalah umur perusahaan (Lianto dan Kusuma, 2010). Umur perusahaan dihitung sejak tahun perusahan tersebut berdiri sampai dengan tahun diterbitkannya laporan keuangan yang digunakan dalam penelitian (Berliana dalam Sahdana, 2011). Menurut Rachmaf Saleh dalam Almilia dan Setiady (2006) perusahaan yang memiliki umur lebih tua cenderung untuk lebih terampil dalam pengumpulan, pemrosesan dan menghasilkan informasi ketika diperlukan dibanding dengan perusahaan yang memiliki umur lebih muda, karena perusahaan yang memiliki umur lebih tua telah memperoleh pengalaman yang cukup dari tahun-tahun sebelumnya serta didukung oleh sumber daya manusia yang sesuai dengan kapasitas dan bidangnya. Selain itu, IIperusahaan yang sudah berusia tua dianggap telah membangun kontrol internal yang lebih baik. Dengan demikian proses audit dapat berjalan lebih cepat, sehingga audit delay berkurang. Jadi, kesimpulannya umur perusahaan berpengaruh terhadap audit delay. Hasil penelitian yang dilakukan oleh Lianto dan Kusuma (2010) menunjukkan bahwa umur perusahaan memiliki pengaruh signifikan terhadap audit delay. Sementara hasil penelitian dari Sugiarto, dkk (2011) menyimpulkan bahwa umur perusahaan tidak berpengaruh terhadap audit delay.

Perbedaan karakteristik industri dapat menyebabkan perbedaan dalam rentang waktu penyelesaian proses audit, salah satu penyebabnya karena perbedaan jumlah dan komposisi 
aset yang dimiliki entitas. Industri dapat diklasifikasikan menjadi industri finansial dan industri non-finansial (Iskandar dan Trisnawati, 2010). Hasil penelitian Ervilah dan Fachriyah (2012) berhasil membuktikan bahwa perusahaan finansial mengalami audit delay yang lebih singkat dibandingkan dengan perusahaan non-finansial. Aset yang dimiliki oleh perusahaan finansial sebagian besar merupakan aset moneter, sehingga lebih mudah diukur dibandingkan dengan aset berbentuk fisik seperti persediaan (Ervilah dan Fachriyah, 2012). Selain itu, perusahaan finansial dinilai lebih memiliki akuntabilitas publik sehingga dokumentasi terhadap segala kegiatan operasional tercatat dan tersimpan dengan baik serta memiliki regulasi yang lebih banyak dibandingkan dengan perusahaan non-finansial, sehingga saat dilakukan proses audit dapat berjalan lebih lancar. Berdasarkan uraian di atas dapat disimpulkan bahwa perbedaan klasifikasi industri berpengaruh terhadap audit delay. Iskandar dan Trisnawati (2010) dalam penelitiannya mendapatkan hasil bahwa klasifikasi industri berpengaruh terhadap audit delay. Sementara hasil penelitian Lianto dan Kusuma (2010) menyatakan bahwa perbedaan jenis industri tidak berpengaruh terhadap audit delay.

Faktor lainnya yang diuji dalam penelitian ini adalah ukuran Kantor Akuntan Publik (KAP). Ketika manajemen perusahaan memilih KAP yang akan digunakan untuk mengaudit laporan keuangannya, maka manajemen akan mempertimbangkan beberapa hal seperti reputasi KAP, kualitas auditor, serta keahlian auditor dalam industri khusus yang terkait dengan kegiatan industri perusahaan. Perusahaan yang telah go public cenderung akan memilih KAP yang mempunyai sumber daya yang lebih memadai karena terkait dengan pertanggungjawaban kepada shareholders-nya dan kepercayaan publik. Waktu audit yang cepat merupakan salah satu cara KAP dengan kualitas yang tinggi untuk mempertahankan reputasi mereka. Menurut Ahmad dan Kamarudin dalam Saputri dan Yuyetta (2012), audit delay pada KAP big four akan lebih pendek dibandingkan dengan audit delay pada KAP kecil. Hal tersebut dikarenakan KAP besar didukung oleh kuantitas yang lebih banyak Oleh karena itu, dapat disimpulkan bahwa ukuran KAP berpengaruh terhadap audit delay. Hasil penelitian yang dilakukan Puspitasari dan Sari (2012) menyatakan bahwa ukuran KAP berpengaruh signifikan terhadap audit delay. Namun, Sumartini dan Widhiyani (2014) memperoleh hasil yang berbeda yaitu bahwa ukuran KAP tidak berpengaruh signifikan terhadap audit delay.

\section{Rumusan Masalah}

Berdasarkan uraian latar belakang di atas, maka dapat dibuat rumusan masalah sebagai berikut :

1. Apakah ukuran perusahaan yang diproksikan dengan total aset berpengaruh terhadap audit delay?

2. Apakah Laba Rugi Operasi berpengaruh terhadap audit delay?

3. Apakah solvabilitas yang diproksikan dengan Total Debt to Total Assets (TDTA) berpengaruh terhadap audit delay?

4. Apakah umur perusahaan berpengaruh terhadap audit delay?

5. Apakah klasifikasi industri berpengaruh terhadap audit delay ?

6. Apakah ukuran KAP berpengaruh terhadap audit delay?

\section{Tinjauan Literatur dan Hipotesis}

\section{Laporan Keuangan}

Laporan keuangan menurut Pernyataan Standar Akuntansi Keuangan (PSAK) No.1 tentang Penyajian Laporan Keuangan (IAI, 2014), adalah suatu penyajian terstruktur dari posisi keuangan dan kinerja keuangan suatu entitas. Tujuan dari laporan keuangan menurut Kerangka Dasar Penyusunan dan Penyajian Laporan Keuangan (IAI, 2014) adalah untuk memberikan informasi mengenai posisi keuangan, kinerja keuangan, dan arus kas entitas yang bermanfaat 
bagi sebagian besar kalangan pengguna laporan dalam pembuatan keputusan ekonomi. Laporan keuangan juga menunjukkan hasil pertanggungjawaban manajemen atas penggunaan sumber daya yang dipercayakan kepada mereka.

\section{Auditing}

Menurut Whittington, O. Ray dan Kurt Pann (2015), definisi auditing adalah proses pemeriksaan laporan keuangan perusahaan oleh perusahaan akuntan publik yang independen. Proses audit terdiri dari investigasi atas catatan akuntansi dan bukti lain yang mendukung laporan keuangan tersebut. Dengan memperoleh pemahaman tentang pengendalian internal perusahaan, dan dengan memeriksa dokumen, mengamati aset, melakukan tanya jawab dengan pihak-pihak di dalam dan luar perusahaan, serta melakukan prosedur audit lainnya, auditor akan mengumpulkan bukti yang diperlukan untuk menentukan apakah laporan keuangan telah disajikan secara wajar dan cukup untuk memberikan gambaran posisi keuangan perusahaan dan kegiatan perusahaan selama periode yang diaudit.

\section{Audit delay}

Menurut Tuanakotta (2011), audit report lag adalah jarak waktu antara tanggal neraca dan tanggal laporan audit. Di sisi lain, menurut Lawrence dan Briyan dalam Yulianti (2010) audit delay adalah lamanya hari yang dibutuhkan auditor untuk menyelesaikan pekerjaan auditnya, yang diukur dari tanggal penutupan tahun buku hingga tanggal diterbitkannya laporan keuangan audit. Iskandar dan Trisnawati (2010) dalam penelitiannya menyatakan bahwa perbedaan waktu antara tanggal laporan keuangan dengan tanggal laporan auditor independen mengindikasikan tentang lamanya waktu penyelesaian audit yang dilakukan oleh auditor, yang sering disebut dengan istilah audit report lag. Audit delay untuk setiap perusahaan dapat berbeda karena ada perbedaan lamanya waktu penyelesaian proses audit untuk masing-masing perusahaan. Jika jarak waktu ini semakin panjang, ditenggarai bahwa hal ini merupakan indikasi adanya masalah, sehingga terjadi proses negosiasi antara klien dan auditornya mengenai bagaimana menyajikan masalah tersebut di dalam laporan keuangan (Tuanakotta, 2011).

\section{Ukuran Perusahaan}

Ukuran perusahaan menggambarkan besar kecilnya suatu perusahaan yang salah satunya ditunjukkan oleh total aset (Puspitasari dan Sari, 2012). Menurut Warren et al. (2008,52) dalam Iskandar dan Trisnawati (2010), assets are the resources owned by physical item, such as cash and supplies, or intangibles that have value. Aset adalah sumber daya yang dikuasai entitas sebagai akibat dari peristiwa masa lalu dan manfaat ekonomi di masa depan diharapkan diperoleh perusahaan (Kartikahadi, dkk, 2012). Menurut PSAK No. 1 (IAI, 2014), entitas mengklasifikasikan aset sebagai aset lancar dan aset tidak lancar.

Menurut Hossain dan Taylor (1998) dalam Puspitasari dan Sari (2012), perusahaan besar akan menyelesaikan audit lebih lama dibandingkan dengan perusahaan kecil, hal ini dikarenakan jumlah sampel yang diambil semakin besar dan semakin banyak prosedur audit yang harus ditempuh. Sementara, menurut Kartika (2011) manajemen perusahaan besar memiliki dorongan untuk mengurangi audit delay oleh karena perusahaan besar senantiasa dimonitor secara ketat oleh investor, asosiasi perdagangan, dan agen regulator. Selain itu, perusahaan besar pada umumnya akan menyelesaikan proses audit lebih cepat dibandingkan dengan perusahaan kecil dikarenakan adanya internal control yang baik dan kemampuan perusahaan untuk mendorong auditornya menyelesaikan pekerjaan audit secara tepat waktu (Iskandar dan Trisnawati, 2010). Hal ini didukung dengan hasil penelitian Ariyani dan 
Budiartha (2014) serta Martia dan Hidayati (2013) bahwa ukuran perusahaan memiliki pengaruh negatif signifikan terhadap audit delay.

Berdasarkan kerangka teori yang telah dijelaskan, maka diajukan hipotesis sebagai berikut.

$\mathrm{Ha}_{1}$ : Ukuran perusahaan berpengaruh terhadap audit delay.

\section{Laba Rugi Operasi}

Laba merupakan salah satu indikator kinerja dari suatu perusahaan karena tujuan utama dari kegiatan operasional perusahaan adalah memperoleh laba. Informasi kinerja manajemen diperlukan investor untuk menilai maupun memprediksi kapasitas kemampuan perusahaan dalam beroperasi. Laba yang menjadi proksi dalam penelitian ini adalah laba operasi (income from operation).

Hasil penelitian Sumartini dan Widhiyani (2014), Iskandar dan Trisnawati (2010), serta Puspitasari dan Sari (2012) menyatakan bahwa laba rugi operasi mempunyai pengaruh negatif dan signifikan terhadap audit delay. Ketika perusahaan mengalami laba, audit delay akan berkurang. Sementara ketika perusahaan mengalami kerugian, audit delay akan bertambah panjang. Perusahaan yang mendapatkan laba tidak ada alasan untuk menunda penerbitan laporan keuangan, bahkan laba tersebut akan membuat calon investor dan investor tertarik, sehingga perusahaan cenderung berkeinginan segera menyampaikan berita baik kepada pasar. Sementara, ketika perusahaan mengalami kerugian, perusahaan akan berusaha untuk menunda bad news sehingga kemungkinan perusahaan akan meminta auditor untuk menjadwal ulang penugasan audit sehingga akhirnya proses audit akan selesai lebih lama.

Berdasarkan kerangka teori yang telah dijelaskan, maka diajukan hipotesis sebagai berikut.

$\mathrm{Ha}_{2}$ : Laba rugi operasi perusahaan berpengaruh terhadap audit delay.

\section{Solvabilitas}

Rasio solvabilitas adalah rasio yang menunjukkan besarnya aset sebuah perusahaan yang didanai dengan utang. Rasio ini menunjukkan kemampuan perusahaan untuk membayar seluruh kewajibannya dengan menggunakan aset, baik kewajiban jangka pendek maupun jangka panjang, jika perusahaan dibubarkan atau dilikuidasi. Dalam penelitian ini solvabilitas diukur dengan menggunakan total debt to total asset ratio (TDTA). TDTA menggambarkan seberapa banyak aset yang dibiayai perusahaan dengan menggunakan utang. Semakin tinggi rasio ini berarti semakin besar jumlah modal pinjaman yang digunakan untuk investasi pada aset guna menghasilkan keuntungan bagi perusahaan. Ada kemungkinan perusahaan tidak dapat melunasi utangnya jika rasio total debt to total asset terlalu tinggi (Weygandt, et al, 2013).

Ketika utang semakin banyak yang mengindikasikan perusahaan maka auditor harus memeriksa lebih banyak dokumen terkait utang dan penggunaannya. sehingga audit delay menjadi panjang. Jadi, semakin tinggi rasio utang terhadap total aset, akan semakin lama rentang waktu yang dibutuhkan untuk penyelesaian audit laporan keuangan tahunan (Puspitasari dan Sari, 2012). Hasil penelitian Febrianty (2011) dan Kartika (2011) menunjukkan bahwa solvabilitas berpengaruh positif dan signifikan terhadap audit delay.

Berdasarkan kerangka teori yang telah dijelaskan, maka diajukan hipotesis sebagai berikut.

Ha3 : Solvabilitas yang diproksikan dengan Total Debt to Total Assets (TDTA) berpengaruh terhadap audit delay. 


\section{Umur Perusahaan}

Umur perusahaan menunjukkan bahwa suatu perusahaan tetap ada, berdiri, dan beroperasi, serta mampu berkompetisi dengan perusahaan lainnya untuk menjalankan kegiatan operasional. Umur perusahaan dalam penelitian ini dihitung berdasarkan tahun berdiri perusahaan yang diaudit (Berliana dalam Sahdana, 2011), yaitu sejak tanggal akta pendirian notaris hingga tahun laporan keuangan perusahaan yang digunakan dalam penelitian diterbitkan.

Petronila (2007) dalam Lianto dan Kusuma (2010) menunjukkan bahwa umur perusahaan berpengaruh negatif terhadap audit report lag. Semakin lama umur perusahaan maka jangka waktu pelaporan auditnya akan semakin cepat dikarenakan perusahaan yang sudah lama berdiri dinilai telah memiliki kontrol internal yang baik. Tetapi, hasil penelitian Lianto dan Kusuma (2010) menunjukkan bahwa umur perusahaan memiliki pengaruh positif dan signifikan terhadap audit delay. Penelitian Togasima dan Christiawan (2014) menemukan adanya pengaruh positif antara umur perusahaan dengan audit delay. Perusahaan yang telah lama berdiri sebagian besar telah melakukan ekspansi dengan membuka cabang-cabang atau dengan bertambahnya jumlah anak perusahaan. Skala operasional perusahaan yang besar ini akan menambah pekerjaan auditor ketika melakukan pemeriksaan. Hal tersebut akan mempengaruhi proses audit yang pada akhirnya mempengaruhi audit report lag (Lianto dan Kusuma, 2010). berikut.

Berdasarkan kerangka teori yang telah dijelaskan, maka diajukan hipotesis sebagai $\mathrm{Ha}_{4}$ : Umur perusahan berpengaruh terhadap audit delay.

\section{Klasifikasi Industri}

Klasifikasi industri merupakan penggolongan jenis industri yang menjadi operasional perusahaan ke dalam suatu kelompok. Jenis industri adalah perbedaan jenis kegiatan perusahaan (Iskandar dan Trisnawati, 2010). Berbagai jenis industri dapat diklasifikasikan berdasarkan kriteria tertentu, seperti modal (industri rumah tangga, industri kecil, industri sedang, dan industri besar), tenaga kerja (industri padat karya atau industri padat modal), departemen industri (industri hulu atau industri hilir), dan jenis usahanya (industri ekstraktif, industri non-ekstraktif, dan industri jasa).

Dalam penelitian ini, jenis industri dibagi menjadi 2 kelompok yaitu industri finansial dan industri non-finansial (Shulthoni, 2012). Karakteristik industri yang berbeda-beda dapat menyebabkan perbedaan rentang waktu dalam proses pelaksanaan audit (Lianto dan Kusuma, 2010). Perusahaan finansial cenderung tidak memiliki persediaan berbentuk fisik, melainkan dalam bentuk moneter (Carslaw dan Kaplan, 1991 dalam Shulthoni, 2012), sehingga ketika proses audit tidak perlu dilakukan cek fisik untuk item persediaan. Iskandar dan Trisnawati (2010) menyatakan bahwa klasifikasi industri berpengaruh terhadap audit report lag. Perusahaan finansial akan mengumumkan laporan keuangannya lebih cepat karena hanya memiliki sedikit persediaan. Almosa dan Alabbas (2007) dalam Shulthoni (2012) juga berargumen bahwa perusahaan dalam industri finansial cenderung memiliki proporsi inventory yang relatif rendah sehingga audit delay lebih rendah dibanding industri non-finansial. berikut.

Berdasarkan kerangka teori yang telah dijelaskan, maka diajukan hipotesis sebagai Ha5 : Klasifikasi Industri berpengaruh terhadap audit delay.

\section{Ukuran Kantor Akuntan Publik (KAP)}

Di dalam Undang-Undang Republik Indonesia No.5 Tahun 2011 disebutkan bahwa, Kantor Akuntan Publik yang selanjutnya disingkat KAP adalah badan usaha yang didirikan berdasarkan ketentuan peraturan perundang-undangan dan mendapatkan izin usaha 
berdasarkan Undang-Undang Republik Indonesia No. 5 Tahun 2011 tentang Akuntan Publik. Ketika manajemen perusahaan memilih KAP yang akan digunakan untuk audit laporan keuangannya, maka manajemen akan mempertimbangkan beberapa hal seperti reputasi KAP, kualitas auditor, serta keahlian auditor dalam industri khusus yang terkait dengan kegiatan industri perusahaan.

Pada penelitian ini, kantor akuntan yang dimaksud dengan Kantor Akuntan Publik besar adalah KAP yang melakukan afiliasi dengan KAP big four. Sementara, Kantor Akuntan Publik kecil adalah KAP yang tidak berafiliasi dengan KAP big four. Kantor Akuntan Publik big four secara umum dianggap sebagai penyedia laporan audit yang berkualitas tinggi, memiliki reputasi yang tinggi pada lingkungan bisnis, dan akan menjaga independensinya untuk mempertahankan citra mereka. Selain itu, KAP yang berafiliasi dengan big four biasanya juga didukung dengan kuantitas sumber daya manusia yang lebih banyak sehingga akan berpengaruh pada kualitas jasa yang dihasilkan. Oleh karena itu, perusahaan yang menggunakan jasa auditor yang berafiliasi dengan big four akan mengalami audit delay yang lebih singkat. Hal ini didukung oleh hasil penelitian Puspitasari dan Sari (2012) dan hasil penelitian Ayemere dan Elijah (2015) yang menyimpulkan bahwa ukuran KAP berpengaruh terhadap audit delay. berikut.

Berdasarkan kerangka teori yang telah dijelaskan, maka diajukan hipotesis sebagai

Ha6 : Ukuran KAP berpengaruh terhadap audit delay.

\section{Model Penelitian}

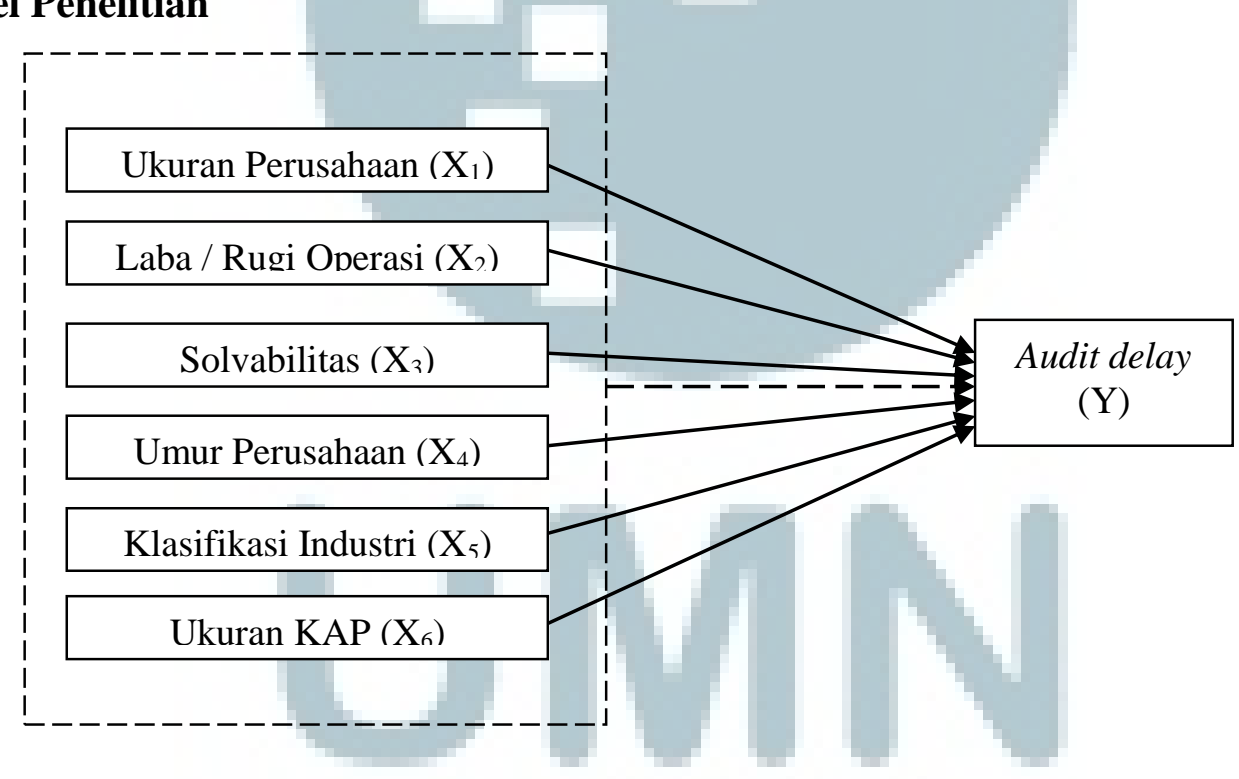

\section{III.Metode Penelitian}

Dalam penelitian ini objek yang diteliti adalah perusahaan Indeks Kompas 100 periode 20122014. Teknik pengambilan sampel yang digunakan adalah purposive sampling. Terdapat 55 perusahaan yang memenuhi keempat kriteria yang telah ditetapkan peneliti, yaitu:

1. Perusahaan yang termasuk dalam Indeks Kompas 100 periode 2012-2014 secara berturut-turut.

2. Perusahaan yang menerbitkan laporan keuangan periode 2012-2014 yang sudah diaudit oleh auditor independen.

3. Laporan keuangan disajikan per 31 Desember dan menggunakan mata uang Rupiah agar dapat diperbandingkan satuan moneternya. 
4. Laporan keuangan memuat secara lengkap data-data terkait variabel penelitian, yaitu : audit delay, ukuran perusahaan, laba rugi operasi, solvabilitas, umur perusahaan, klasifikasi industri, dan ukuran Kantor Akuntan Publik.

\section{Variabel Penelitian \\ Audit Delay}

Audit delay diukur dengan menghitung selisih waktu antara tanggal penutupan buku perusahaan dengan tanggal yang tertera dalam laporan keuangan auditan (Puspitasari dan Sari, 2012).

Audit Delay $=$ Tanggal laporan audit - Tanggal tutup buku perusahaan

Variabel ini diukur secara kuantitantif dalam jumlah hari. Skala pengukurannya adalah skala rasio. Skala rasio adalah skala interval dan memiliki nilai dasar (based value) yang tidak dapat dirubah (Ghozali, 2013).

\section{Ukuran Perusahaan}

Ukuran perusahaan $\left(\mathrm{X}_{1}\right)$ adalah besar atau kecilnya perusahaan, dalam penelitian ini dilihat dari jumlah aset yang dimiliki perusahaan (Martia dan Hidayati, 2013). Ukuran perusahaan diukur melalui logaritma total aset. Skala pengukurannya adalah skala rasio. Penggunaan logaritma $(\mathrm{Log})$ dalam penelitian ini dimaksudkan untuk mengurangi fluktuasi data yang berlebih (Modugu, et al, 2012).

\section{Ukuran perusahaan $=\log ($ total aset $)$}

\section{Laba Rugi Operasi}

Selisih antara pendapatan dan biaya operasi yang dikeluarkan oleh perusahaan kemudian disebut laba rugi operasi perusahaan (Himayati, 2008). Laba rugi operasi $\left(\mathrm{X}_{2}\right)$ diperoleh dari selisih antara laba kotor dengan beban operasional (Kieso, et al, 2013).

Variabel ini diukur dengan skala nominal menggunakan variabel dummy. Untuk perusahaan yang mengalami kerugian maka akan diberi kode 0 dan untuk perusahaan yang mengalami laba diberi kode 1 (Puspitasari dan Sari, 2012).

\section{Solvabilitas}

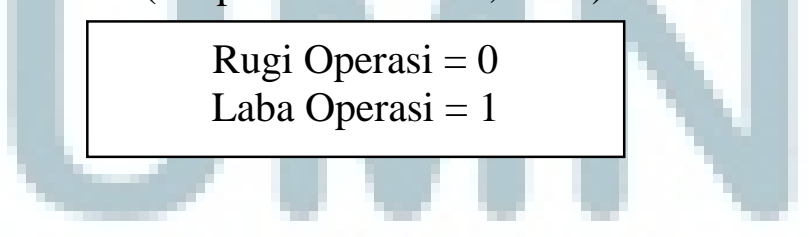

Solvabilitas $\left(\mathrm{X}_{3}\right)$ dalam penelitian ini diproksikan dengan rasio Total Debt to Total Assets (TDTA). Skala yang digunakan untuk mengukur variabel independen ini adalah skala rasio. Tujuan dari menghitung rasio TDTA adalah mengukur seberapa banyak utang yang digunakan untuk membiayai aset perusahaan, baik aset tetap maupun aset lancar. TDTA dapat dihitung menggunakan rumus (Weygandt et al, 2013):

$$
\text { Total Debt to Total Asset Ratio }=\frac{\text { Total Debt }}{\text { Total Assets }} \times 100 \%
$$

\section{Umur Perusahaan}

Umur perusahaan $\left(\mathrm{X}_{4}\right)$ dihitung berdasarkan tahun berdiri perusahaan yang diaudit (Berliana dalam Sahdana, 2011), yaitu sejak tanggal akta pendirian notaris hingga tahun tutup buku 
laporan keuangan perusahaan yang digunakan dalam penelitian. Skala pengukuran yang digunakan adalah skala rasio.

$$
\text { Umur Perusahaan }=\text { Tahun laporan keuangan }- \text { tahun akta pendirian }
$$

\section{Klasifikasi Industri}

Klasifikasi industri $\left(\mathrm{X}_{5}\right)$ adalah pengklasifikasian jenis kegiatan perusahaan. Industri dapat diklasifikasikan menjadi industri finansial dan industri non-finansial (Iskandar dan Trisnawati, 2010). Skala pengukuran variabel ini adalah skala nominal. Variabel ini diukur dengan menggunakan dummy, untuk industri non-finansial diberi kode 0 dan untuk industri finansial diberi kode 1, berdasar pada penelitian Iskandar dan Trisnawati (2010).

\section{Ukuran KAP}

Ukuran Kantor Akuntan Publik $\left(\mathrm{X}_{6}\right)$ diukur dengan membagi perusahaan yang menggunakan jasa KAP menjadi dua, yaitu KAP dengan afiliasi big four dan KAP dengan afiliasi non big four. Variabel ini diukur dengan menggunakan variabel dummy. Skala yang digunakan untuk mengukur Kantor Akuntan Publik adalah skala nominal. Perusahaan yang menggunakan jasa KAP dengan afiliasi non big four diberi kode 0 , sementara perusahaan yang menggunakan jasa KAP dengan afiliasi big four diberi kode 1, hal ini berdasarkan penelitian yang dilakukan Puspitasari dan Sari (2012) dan Shulthoni (2013).

Menggunakan Jasa KAP dengan afiliasi non- big four $=0$

Menggunakan Jasa KAP dengan afiliasi big four $=1$

\section{Metode Analisis}

Pengujian hipotesis dalam penelitian ini menggunakan model regresi berganda untuk memperoleh gambaran menyeluruh terkait dengan pengaruh ukuran perusahaan, laba rugi operasi, solvabilitas, umur perusahaan, klasifikasi industri, dan ukuran KAP terhadap audit delay, dengan model persamaan sebagai berikut

\section{Persamaan 3.1 Persamaan Regresi}

$$
Y=\alpha+\beta_{1} X_{1}+\beta_{2} X_{2}+\beta_{3} X_{3}+\beta_{4} X_{4}+\beta_{5} X_{5}+\beta_{6} X_{6}+e
$$

$\begin{array}{lll}\text { Keterangan : } & & \\ \mathrm{Y} & = & \text { Audit Delay } \\ \alpha & = & \text { Konstanta } \\ \mathrm{X}_{1} & = & \text { Ukuran Perusahaan (Log Total Aset) } \\ \mathrm{X}_{2} & = & \text { Laba rugi operasi } \\ \mathrm{X}_{3} & = & \text { Solvabilitas (TDTA) } \\ \mathrm{X}_{4} & = & \text { Umur Perusahaan } \\ \mathrm{X}_{5} & = & \text { Klasifikasi Industri } \\ \mathrm{X}_{6} & = & \text { Ukuran KAP } \\ \beta_{1}, \beta_{2, \ldots,}, \beta_{6} & = & \text { Koefisien regresi parsial untuk } \\ \mathrm{e} & & \text { masing-masing variabel independen } \\ & = & \text { Kesalahan faktor pengganggu }\end{array}$




\section{Hasil dan Pembahasan}

\section{Statistik Deskriptif}

Statistik deskriptif memberikan gambaran atau deskripsi suatu data yang dilihat dari nilai ratarata (mean), standar deviasi, maksimum, minimum, dan range (Ghozali, 2012).

Tabel 4.1 Hasil Uji Statistik Deskriptif Industri Finansial Descriptive Statistics

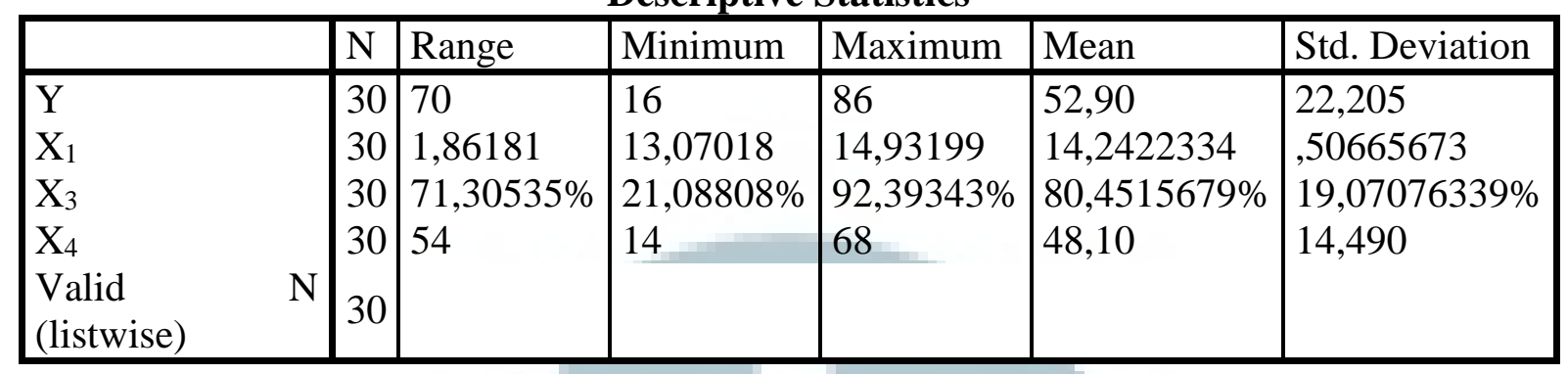

Tabel 4.2 Hasil Uji Statistik Deskriptif Industri Non-Finansial Descriptive Statistics

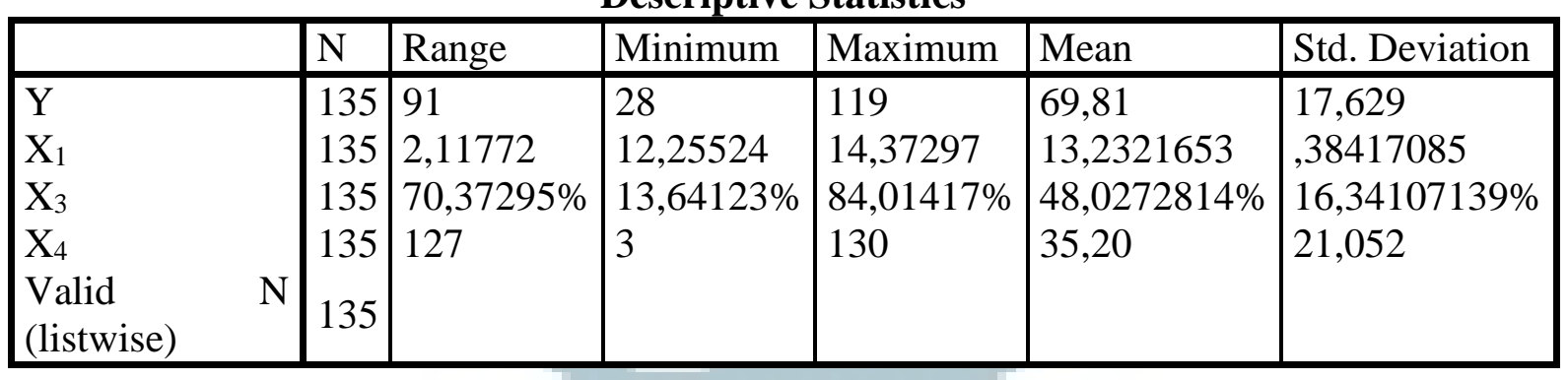

Nilai mean (rata-rata) audit delay untuk 30 perusahaan finansial yang menjadi sampel dalam penelitian ini adalah sepanjang 53 hari dengan standar deviasi sebesar 22,20. Berdasarkan penjelasan di atas, 30 perusahaan finansial yang menjadi sampel dalam penelitian ini tidak terlambat melakukan publikasi laporan keuangan auditan karena audit delay yang dialami oleh perusahaan kurang dari 90 hari.

Nilai mean (rata-rata) audit delay untuk 135 perusahaan non-finansial yang menjadi sampel dalam penelitian ini adalah sepanjang 70 hari dengan standar deviasi sebesar 17,62. Artinya, rata-rata perusahaan non-finansial sudah tepat waktu mempublikasikan laporan keuangan auditan, hanya terdapat 4 perusahaan yang melakukan publikasi melewati batas waktu yang ditentukan. 


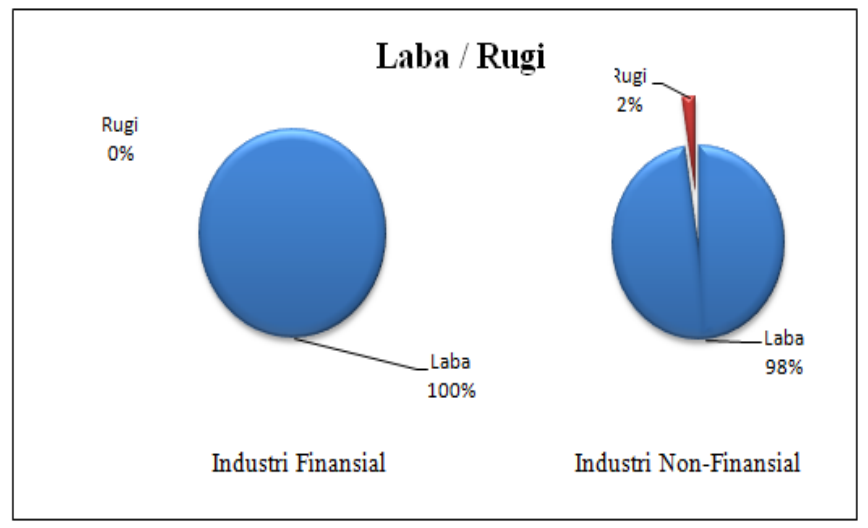

Sumber : Data olahan

\section{Gambar 4.1 Diagram Perusahaan yang Mengalami Laba Rugi Operasi}

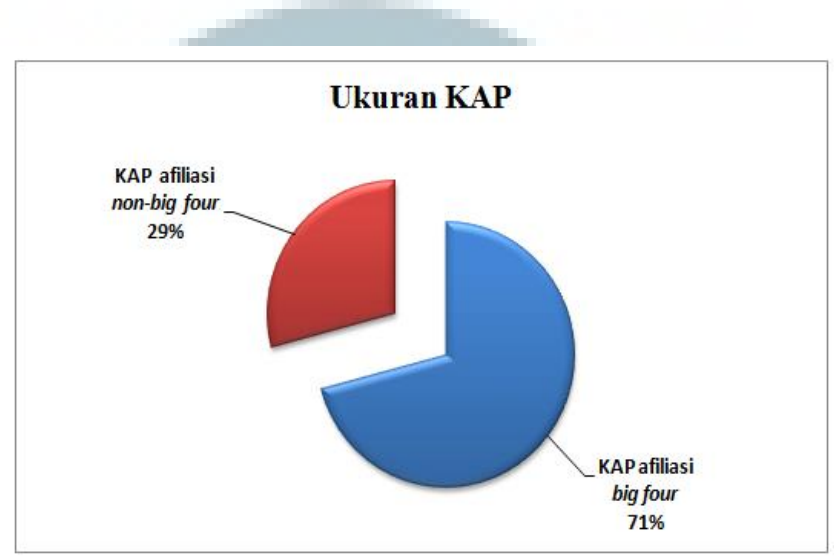

\section{Gambar 4.2 Diagram Ukuran Kantor Akuntan Publik (KAP)}

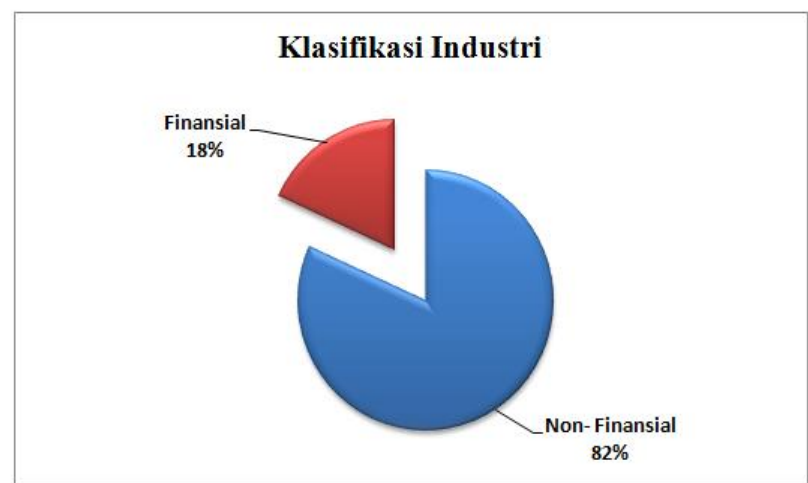

Gambar 4.3 Diagram Klasifikasi Industri

Hasil deskriptif 30 perusahaan industri finansial yang menjadi sampel dalam penelitian ini menunjukkan bahwa 100\% sampel memperoleh laba operasi pada tahun 2012-2014. Sementara untuk 135 sampel industri non-finansial 98\% mengalami laba. Artinya, dalam data sampel hanya 4 perusahaan yang mengalami kerugian dalam operasionalnya, sementara sebanyak 131 perusahaan sampel memperoleh laba operasi pada.tahun 2012-2014.

Hasil deskriptif menunjukkan bahwa $82 \%$ sampel atau 135 perusahaan merupakan perusahaan yang bergerak dalam bidang non-finansial dan 18\% sampel atau 30 perusahaan yang diklasifikasikan sebagai perusahaan yang bergerak dalam bidang finansial. 
Hasil deskriptif menunjukkan bahwa 29\% sampel atau 48 perusahaan diaudit oleh KAP yang tidak berafiliasi dengan big four dan $71 \%$ atau 117 sampel diaudit oleh KAP yang berafiliasi dengan big four.

\section{Uji Kualitas Data}

Hasil pengujian Kolmogorov-Smirnov yang dihasilkan menunjukkan nilai signifikansi sebesar 0,095. Berdasarkan pengujian tersebut, nilai signifikansi lebih besar dari 0,05, maka data tersebut terdistribusi secara normal.

Tabel 4.3 Hasil Uji Normalitas

One-Sample Kolmogorov-Smirnov Test

\begin{tabular}{|ll|l|}
\hline & & \multicolumn{1}{|c|}{$\begin{array}{c}\text { Unstandardized } \\
\text { Residual }\end{array}$} \\
\hline $\mathrm{N}$ & Mean & 165 \\
Normal Parameters & a,b & Std. \\
& Deviation & 16,84000002257 \\
Most Extreme & Absolute &, 096 \\
Differences & Positive &, 088 \\
Kolmogorov-Smirnov Z & Negative &,- 096 \\
Asymp. Sig. (2-tailed) & 1,234 \\
\hline
\end{tabular}

a. Test distribution is Normal.

b. Calculated from data.

\section{Uji Asumsi Klasik}

\section{Multikolonieritas}

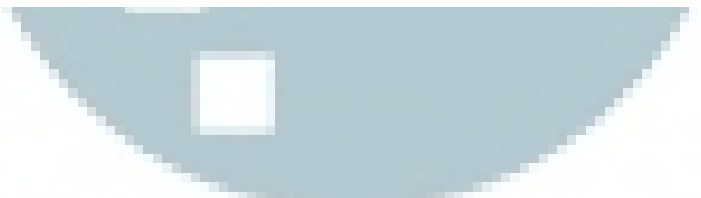

Uji multikolonieritas bertujuan untuk menguji apakah pada model regresi ditemukan adanya korelasi antar variabel independen. Model regresi yang baik seharusnya tidak terjadi korelasi antar variabel independen (Ghozali, 2013). Hasil uji multikolonieritas dalam penelitian ini adalah:

\section{Tabel 4.4 Hasil Uji Multikolonieritas}

\section{Coefficients $^{\mathrm{a}}$}

\begin{tabular}{|c|c|c|}
\hline \multirow[t]{2}{*}{ Model } & \multicolumn{2}{|c|}{ Collinearity Statistics } \\
\hline & Tolerance & VIF \\
\hline (Constant) & & \\
\hline $\mathrm{X}_{1}$ & ,375 & 2,668 \\
\hline$X_{2}$ & ,985 & 1,016 \\
\hline $1 \mathrm{X}_{3}$ & ,592 & 1,691 \\
\hline $\mathrm{X}_{4}$ & ,846 & 1,182 \\
\hline $\mathrm{X}_{5}$ & ,425 & 2,354 \\
\hline $\mathrm{X}_{6}$ & 695 & 1,439 \\
\hline
\end{tabular}

a. Dependent Variable: Y 
Berdasarkan hasil pengujian dapat disimpulkan tidak terjadi multikolonieritas antar variabel independen, karena seluruh variabel independen memiliki nilai VIF kurang dari 10 dan nilai Tolerance lebih dari 0,10 .

\section{Heteroskedastisitas}

Pengujian ini dilakukan untuk mengetahui apakah dalam model regresi terjadi ketidaksamaan variance dari residual satu pengamatan ke pengamatan yang lain (Ghozali, 2013).

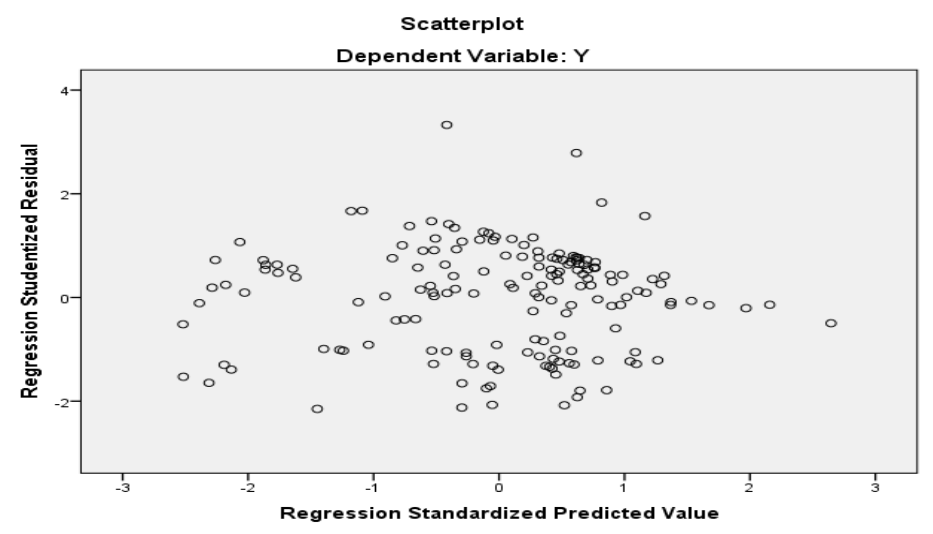

Gambar 4.4 Hasil Uji Heteroskedastisitas

Berdasarkan grafik plot dapat dillihat bahwa titik-titik menyebar secara acak, baik diatas maupun dibawah angka nol pada sumbu $\mathrm{Y}$ dan tidak berbentuk pola tertentu secara teratur. Sehingga dapat disimpulkan bahwa pada model regresi penelitian ini tidak terjadi heteroskedastisitas, maka model regresi layak digunakan dalam penelitian.

\section{Autokorelasi}

Pengujian ini bertujuan untuk menguji apakah dalam model regresi terdapat korelasi antara kesalahan pengganggu pada periode $\mathrm{t}$ dengan kesalahan pengganggu pada periode $\mathrm{t}-1$ (sebelumnya). Dalam penelitian ini, autokorelasi diuji dengan menggunakan Uji DurbinWatson (DW Test).

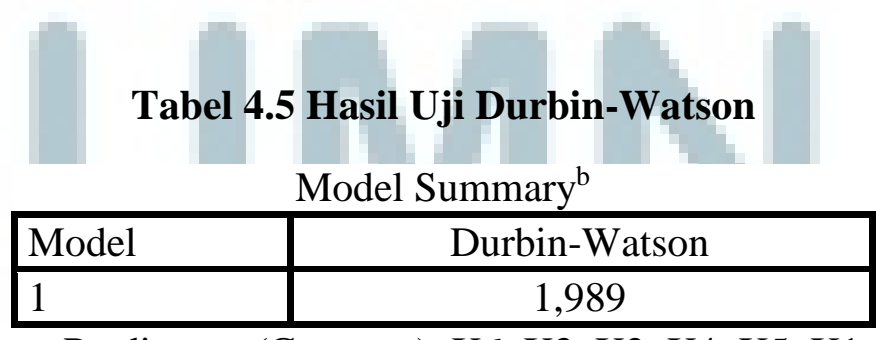

a. Predictors: (Constant), X6, X3, X2, X4, X5, X1

b. Dependent Variable: Y

Berdasarkan hasil pengujian autokorelasi, diperoleh hasil nilai d sebesar 1,989. Jumlah sampel $(n)=165$. Jumlah variabel independen $(k)=6$. Nilai $\mathrm{dl}=1,6707$ dan nilai $\mathrm{du}=1,8212$. Jika nilai di atas dimasukkan ke dalam rumus $\mathrm{du}<\mathrm{d}<4$-du, maka diperoleh hasil 1,8212 < 1,989 $<2,1788$. Hal tersebut menunjukkan bahwa tidak terjadi autokorelasi baik positif maupun negatif. 


\section{Uji Hipotesis}

\section{Uji Koefisien Determinasi}

Pengujian Hipotesis dilakukan untuk mengetahui pengaruh variabel ukuran perusahaan, laba rugi operasi, solvabilitas, umur perusahaan, klasifikasi industri, dan ukuran KAP terhadap audit delay secara parsial dan simultan. Hasil pengujian hipotesis dapat dilihat melalui analisis regresi berganda berikut ini :

\section{Tabel 4.6 Hasil Uji Hipotesis}

\begin{tabular}{|l|c|c|c|c|}
\hline Model & R & R Square & Adjusted R Square & Std. Error of the Estimate \\
\hline 1 &, $511^{\mathrm{a}}$ &, 261 &, 233 & 17,157 \\
\hline
\end{tabular}

a. Predictors: (Constant), X6, X3, X2, X4, X5, X1

b. Dependent Variable: Y

Hasil pengujian hipotesis memperoleh nilai $\mathrm{R}$ sebesar 0,511 . Berdasarkan nilai $\mathrm{R}$ tersebut, dapat dikatakan bahwa korelasi atau hubungan antara variabel dependen dengan variabel independen dianggap kuat, karena nilai tersebut berada dalam kriteria $>0,5-0,75$ (Sarwono, 2012). Nilai adjusted $R^{2}$ yang diperoleh adalah 0,233. Artinya, seluruh variabel independen dalam penelitian ini mampu menjelaskan variasi dari variabel dependen sebesar $23,3 \%$, sedangkan sisanya sebesar $76,7 \%$ dijelaskan oleh faktor-faktor lain yang tidak termasuk dalam model penelitian ini.

\section{Uji Signifikansi Simultan (Uji Statistik F)}

Tujuan dari Uji Statistik F adalah untuk mengetahui apakah semua variabel independen dalam penelitian, yaitu ukuran perusahaan $\left(\mathrm{X}_{1}\right)$, laba rugi operasi $\left(\mathrm{X}_{2}\right)$, solvabilitas $\left(\mathrm{X}_{3}\right)$, umur perusahaan $\left(\mathrm{X}_{4}\right)$, klasifikasi industri $\left(\mathrm{X}_{5}\right)$, dan ukuran $\mathrm{KAP}\left(\mathrm{X}_{6}\right)$ berpengaruh secara simultan terhadap variabel dependen audit delay. Berikut ini adalah hasil dari uji statistik F :

Tabel 4.7 Hasil Uji Signifikansi Simultan (Uji Statistik F)

ANOVA ${ }^{a}$

\begin{tabular}{|c|c|c|c|c|c|c|}
\hline \multicolumn{2}{|c|}{ Model } & $\begin{array}{c}\text { Sum of } \\
\text { Squares }\end{array}$ & Df & $\begin{array}{l}\text { Mean } \\
\text { Square }\end{array}$ & $\bar{F}$ & Sig. \\
\hline \multirow{3}{*}{1} & Regression & 16459,631 & 6 & 2743,272 & 9,320 &, $000^{b}$ \\
\hline & Residual & 46508,163 & 158 & 294,355 & & \\
\hline & Total & 62967,794 & 164 & & & \\
\hline
\end{tabular}

a. Dependent Variable: Y

b. Predictors: (Constant), X6, X3, X2, X4, X5, X1

Artinya, model dalam penelitian ini dapat digunakan untuk memprediksi nilai observasi atau pengamatan. Hasil penelitian ini sejalan dengan hasil penelitian Puspitasari dan Sari (2012) yang berhasil membuktikan bahwa faktor ukuran perusahaan, solvabilitas, laba rugi perusahaan, dan ukuran KAP berpengaruh secara simultan terhadap audit delay pada perusahaan manufaktur yang terdaftar di Bursa Efek Indonesia tahun 2007-2010

\section{Uji Signifikansi Parameter Individual (Uji Statistik t)}

Uji statistik t dilakukan untuk mengetahui apakah semua variabel independen dalam penelitian memiliki pengaruh individual terhadap audit delay. Berikut merupakan hasil uji statistik t: 
Tabel 4.8 Hasil Uji Signifikansi Parameter Individual (Uji Statistik t)

Coefficients $^{\mathrm{a}}$

\begin{tabular}{|l|c|c|c|c|c|}
\hline \multirow{2}{*}{ Model } & \multicolumn{2}{|c|}{ Unstandardized Coefficients } & Standardized Coefficients & $\mathrm{t}$ & Sig. \\
\cline { 2 - 5 } & $\mathrm{B}$ & Std. Error & Beta & & \\
\hline (Constant) & 326,452 & 49,683 & & 6,571 &, 000 \\
$\mathrm{X}_{1}$ & $-19,189$ & 3,877 &,- 553 & $-4,950$ &, 000 \\
$\mathrm{X}_{2}$ & $-9,715$ & 8,752 &,- 076 & $-1,110$ &, 269 \\
$1 \mathrm{X}_{3}$ &, 119 &, 083 &, 128 & 1,436 &, 153 \\
$\mathrm{X}_{4}$ &,- 042 &, 071 &,- 044 &,- 591 &, 555 \\
$\mathrm{X}_{5}$ & $-1,427$ & 5,313 &,- 028 &,- 269 &, 789 \\
$\mathrm{X}_{6}$ & 3,664 & 3,528 &, 085 & 1,039 &, 301 \\
\hline
\end{tabular}

a. Dependent Variable: Y

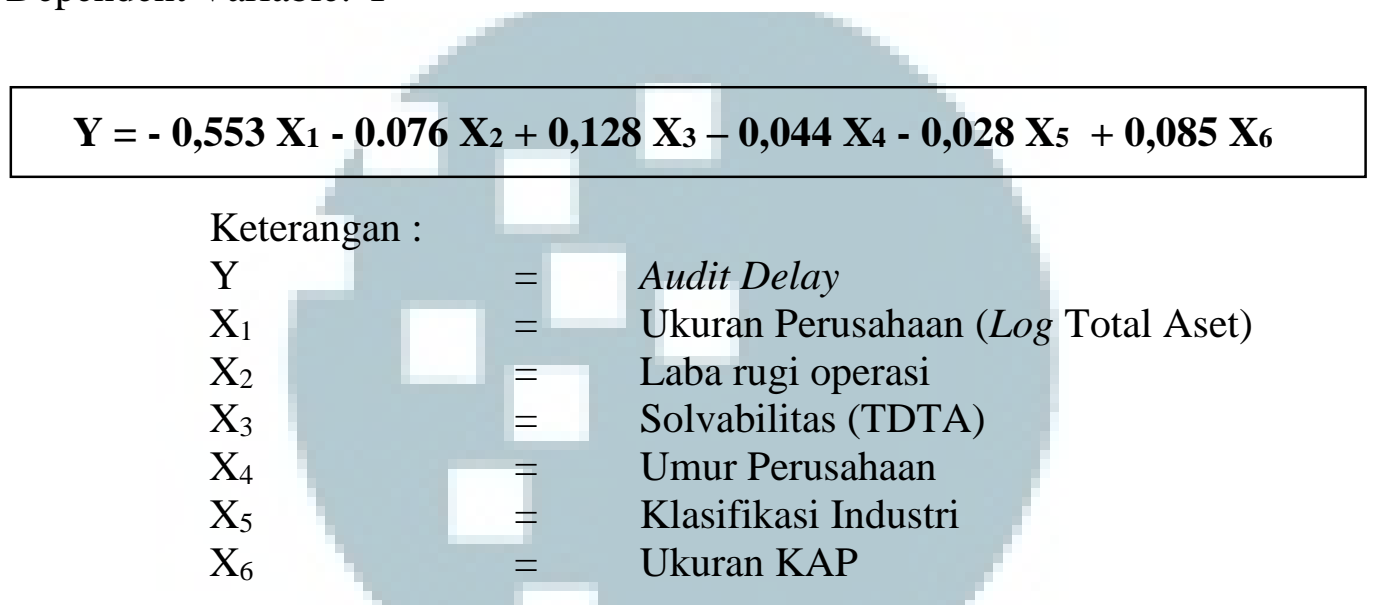

Berdasarkan tabel, untuk variabel ukuran perusahaan $\left(\mathrm{X}_{1}\right)$ memperoleh koefisien regresi sebesar $-0,553$ yang artinya, bahwa setiap kenaikan ukuran perusahaan $\left(\mathrm{X}_{1}\right)$ sebesar $1 \%$ maka audit delay (Y) akan menurun sebesar 0,553 atau 55,3\%. Variabel ukuran perusahaan $\left(\mathrm{X}_{1}\right)$ memiliki nilai t sebesar -4,950 dengan tingkat signifikansi sebesar 0,000 atau lebih kecil dari 0,05. Artinya $\mathrm{Ha}_{1}$ diterima, berarti ukuran perusahaan berpengaruh signifikan terhadap audit delay. Hasil penelitian ini menunjukkan jika ukuran perusahaan semakin besar maka akan mengurangi audit delay, Hal ini dapat dibuktikan dari contoh sampel perusahaan finansial BBRI di tahun 2013 mengalami audit delay selama 16 hari dengan ukuran perusahaan yang diproksikan dengan log total asset mendapat hasil sebesar 14,79. Sementara, sampel PNLF di tahun 2012 mengalami audit delay selama 85 hari dengan ukuran perusahaan yang diproksikan dengan log total asset mendapat hasil sebesar 13,07. Selanjutnya, perusahaan non-finansial ASII di tahun 2012 mengalami audit delay selama 57 hari dengan ukuran perusahaan yang diproksikan dengan log total asset mendapat hasil sebesar 14,26. Sementara, sampel MAIN di tahun 2012 mengalami audit delay selama 86 hari dengan ukuran perusahaan yang diproksikan dengan log total asset mendapat hasil sebesar 12,25. Berdasarkan sampel tersebut menunjukkan bahwa, ketika ukuran perusahaan semakin meningkat menyebabkan audit delay berkurang. Hasil penelitian ini sejalan dengan penelitian Iskandar dan Trisnawati (2010), Febrianty (2011), dan Kartika (2011) yang membuktikan bahwa ukuran perusahaan berpengaruh terhadap audit delay. Hasil ini tidak sejalan dengan penelitian Aditya dan Anisyukurlillah (2014) yang menyatakan berapapun kenaikan atau penurunan ukuran perusahaan (size) tidak akan berpengaruh pada kenaikan atau penurunan audit delay.

Koefisien regresi variabel laba rugi operasi $\left(\mathrm{X}_{2}\right)$ memperoleh hasil sebesar -0,076 yang artinya, setiap ada kenaikan variabel laba atau rugi operasi sebesar 1 satuan maka audit delay 
(Y) akan menurun sebesar 0,076 atau 7,6\%. Variabel laba rugi operasi $\left(\mathrm{X}_{2}\right)$ memiliki nilai t sebesar -1,110 dengan tingkat signifikansi sebesar 0,269 atau lebih besar dari 0,05. Artinya $\mathrm{Ha}_{2}$ ditolak, berarti laba rugi perusahaan tidak berpengaruh terhadap audit delay. Hal ini disebabkan karena setiap perusahaan baik yang menghasilkan laba maupun rugi dalam kegiatan operasinya diwajibkan untuk melakukan publikasi laporan keuangan paling lambat 90 hari setelah tanggal penutupan laporan keuangan perusahaan menurut peraturan OJK X.K.2/2011. Selain itu, perusahaan berusaha untuk tetap menjaga kepercayaan dari para investor sehingga perusahaan tetap akan mempublikasikan hasil laporan keuangan auditnya secara tepat waktu baik memperoleh laba maupun rugi dalam operasinya. Bukti dalam penelitian ini adalah, sampel ANTM pada tahun 2014 yang memperoleh kerugian operasi mengalami audit delay selama 62 hari, sementara AISA pada tahun 2013 memperoleh laba namun mengalami audit delay selama 105 hari. Hal tersebut membuktikan bahwa ketika sebuah perusahaan memperoleh laba dalam kegiatan operasionalnya, maka tidak berarti bahwa audit delay akan berkurang. Hal ini juga didukung oleh hasil statistik deskriptif yang menyatakan bahwa sampel dalam penelitian ini baik untuk sektor finansial maupun non finansial, didominasi oleh perusahaan yang mengalami profit selama periode penelitian. Perusahaan yang mengalami kerugian hanya $2 \%$ dari jumlah keseluruhan perusahaan sektor non finansial sehingga hal ini menyebabakan laba atau rugi tidak mempengaruhi audit delay. Hasil penelitian ini sejalan dengan penelitian yang dilakukan oleh Kartika (2011) dan Modugu et al (2012) yang menyatakan bahwa laba rugi perusahaan tidak berpengaruh terhadap audit delay. Namun, berbanding terbalik dengan Puspitasari dan Sari (2012) yang berhasil membuktikan bahwa laba rugi perusahaan mempunyai pengaruh negatif dan signifikan terhadap audit delay.

Koefisien regresi variabel solvabilitas $\left(\mathrm{X}_{3}\right)$ yang diproksikan dengan TDTA (Total Debt to Total Asset Ratio) sebesar 0,128 yang artinya, bahwa setiap kenaikan solvabilitas sebesar $1 \%$ maka audit delay (Y) akan meningkat sebesar 0,128 atau 12,8\%. Variabel solvabilitas $\left(\mathrm{X}_{3}\right)$ memiliki nilai t sebesar 1,436 dengan tingkat signifikansi sebesar 0,153 atau lebih besar dari 0,05. Dengan demikian $\mathrm{Ha}_{3}$ ditolak, yang artinya adalah solvabilitas yang diproksikan dengan TDTA tidak berpengaruh terhadap audit delay. Hasil penelitian ini menunjukkan bahwa audit delay tidak dipengaruhi oleh tinggi atau rendahnya proporsi utang terhadap aset. Rasio TDTA yang tinggi menunjukkan proporsi utang yang lebih tinggi dibandingkan dengan aset yang dimiliki perusahaan. Rasio TDTA yang semakin tinggi pada sampel perusahaan penelitian ini dianggap tidak berpengaruh selama manajemen perusahaan dapat memberikan dokumen terkait utang tersebut dan penggunaan utang tersebut kepada pihak auditor, karena manajemen berupaya agar dapat menyerahkan laporan keuangan kepada pihak Otoritas Jasa Keuangan sebelum batas waktu yang ditetapkan dalam peraturan OJK X.K.2/2011. Hasil ini didukung menggunakan data sampel yang diolah, untuk perusahaan finansial BDMN tahun 2012 memiliki rasio solvabilitas sebesar 81,55\% dengan audit delay 37 hari, sementara PNLF di tahun 2012 dengan rasio solvabilitas sebesar 29,35\% dengan audit delay 85 hari .Untuk perusahaan non-finansial pada tahun 2014 SMCB dengan rasio TDTA sebesar 49,06\% memiliki audit delay sepanjang 48 hari, sementara INTP pada tahun 2014 dengan rasio TDTA sebesar 13,64\% memiliki audit delay sepanjang 66 hari. Hal tersebut membuktikan bahwa, semakin besar rasio TDTA tidak menjamin audit delay akan semakin meningkat. Hasil penelitian ini sejalan dengan penelitian yang dilakukan oleh Iskandar dan Trisnawati (2010) yang memperoleh hasil bahwa debt proportion tidak berpengaruh terhadap audit delay dan penelitian Sumartini dan Widhiyani (2014) yang membuktikan bahwa solvabilitas tidak berpengaruh terhadap audit delay. Namun, hasil penelitian ini berbanding terbalik dengan hasil Kartika (2011), yang menyatakan bahwa solvabilitas berpengaruh positif signifikan terhadap audit delay.

Koefisien regresi dari variabel umur perusahaan $\left(\mathrm{X}_{4}\right)$ sebesar -0,044 yang artinya, bahwa setiap kenaikan umur perusahaan sebesar $1 \%$ maka audit delay (Y) akan menurun 
sebesar 0,044 atau 4,4\%. Variabel umur perusahaan $\left(\mathrm{X}_{4}\right)$ memiliki nilai t sebesar -0,591 dengan tingkat signifikansi sebesar 0,555 atau lebih besar dari 0,05. Artinya Ha4 ditolak, berarti umur perusahaan tidak berpengaruh terhadap audit delay. Hasil penelitian ini menunjukkan bahwa umur perusahaan tidak berpengaruh signifikan terhadap audit delay, baik perusahaan baru maupun perusahaan lama akan berusaha untuk segera menyelesaikan proses audit karena mereka diawasi secara ketat oleh para investor, pemerintah, dan lembaga lainnya dan setiap perusahaan akan berupaya untuk mempublikasikan laporan keuangannya secara tepat waktu. Salah satu cara bagi perusahaan yang baru berdiri atau tergolong perusahaan muda untuk menarik perhatian investor ialah melalui laporan kinerja mereka, yaitu laporan keuangan. Sementara, perusahaan yang umurnya sudah tua atau sudah lama beroperasi akan berupaya agar laporan keuangan dapat dipublikasikan tepat waktu untuk tetap mempertahankan kepercayaan atau loyalitas dari para investor yang telah dimiliki sejak lama. Dalam sampel penelitian ini perusahaan TLKM di tahun 2014 yang memiliki umur 130 tahun mengalami audit delay selama 58 hari, sementara perusahaan EXCL di tahun 2014 yang memiliki umur 25 tahun mengalami audit delay selama 36 hari. Hal tersebut membuktikan bahwa umur perusahaan yang semakin tua tidak selalu membuat audit delay berkurang. Hasil penelitian ini sejalan dengan penelitian Sugiarto, dkk (2011) yang menunjukkan bahwa tidak terdapat pengaruh antara umur perusahaan terhadap audit delay. Namun, tidak sejalan dengan hasil penelitian Lianto dan Kusuma (2010) yang menyatakan bahwa umur perusahaan memiliki pengaruh negatif dan signifikan terhadap audit delay.

Koefisien regresi dari variabel klasifikasi industri $\left(\mathrm{X}_{5}\right)$ sebesar $-0,028$ yang artinya, bahwa setiap kenaikan klasifikasi industri sebesar 1 satuan maka audit delay (Y) akan menurun sebesar 0,028 atau 2,8\%. Variabel klasifikasi industri $\left(\mathrm{X}_{5}\right)$ memiliki nilai t sebesar $-0,269$ dengan nilai signifikansi 0,789 yang lebih besar dari 0,05. Artinya Has ditolak, berarti klasifikasi industri tidak berpengaruh terhadap audit delay. Hal ini didukung oleh hasil statistik deskriptif yang menyatakan bahwa jumlah perusahaan sektor fiannsial hanya sebanyak $18 \%$ dari total sampel sehingga tidak mempengaruhi audit delay. Hal ini juga didukung oleh hasil statistik deskriptif yang menunjukkan bahwa sebagian besar sampel yang digunakan dalam penelitain berasal dari perusahaan sektor non finansial yatu sebanyak $71 \%$ dari total sampel. Disamping itu, auditor tetap akan melakukan pengecekan terhadap aset moneter dan dokumendokumen pendukungnya selama proses audit. KAP juga akan mempertimbangkan jumlah staff yang ditugaskan untuk mengaudit baik perusahaan finansial maupun non-finansial yang juga telah memiliki kemampuan dan pengalaman di bidangnya, sehingga pada saat proses audit untuk persediaan yang komposisinya berbeda antar perusahaan finansial dan non-finansial tidak terdapat kendala. Salah satu hasil dari sampel dalam penelitian ini di bidang non-finansial yaitu perusahaan AALI pada tahun 2012 mengalami audit delay selama 51 hari, BSDE pada tahun 2013 mengalami audit delay selama 45 hari, sementara sampel di bidang finansial BJBR pada tahun 2012 mengalami audit delay selama 63 hari dan BBKP pada tahun 2013 mengalami audit delay selama 73 hari. Hal ini menunjukkan bahwa, klasifikasi industri finansial dan nonfinansial tidak mempengaruhi audit delay. Hasil penelitian ini sejalan dengan penelitian Lianto dan Kusuma (2010) yang mendapatkan hasil bahwa jenis industri tidak memiliki pengaruh terhadap audit delay. Sementara itu, hasil ini bertolak belakang dengan hasil penelitian Iskandar dan Trisnawati (2010) yang mendapatkan hasil bahwa jenis industri berpengaruh terhadap audit delay, dimana perusahaan finansial biasanya mengumumkan laporan keuangannya lebih cepat karena hanya sedikit memiliki inventory.

Koefisien regresi variabel ukuran Kantor Akuntan Publik (KAP) (X) sebesar 0,085 yang artinya, bahwa setiap kenaikan ukuran KAP sebesar 1 satuan maka audit delay (Y) akan meningkat sebesar 0,085 atau 8,5\%. Variabel ukuran kantor akuntan publik $\left(\mathrm{X}_{6}\right)$ memiliki nilai t sebesar 1,039 dengan tingkat signifikansi sebesar 0,301 atau lebih besar dari 0,05. Artinya $\mathrm{Ha}_{6}$ ditolak, dimana variabel ukuran Kantor Akuntan Publik (KAP) tidak berpengaruh terhadap 
audit delay. Secara umum, KAP yang berafiliasi dengan KAP big four dipandang dapat mengurangi audit delay karena pada umumnya KAP besar akan memiliki sumber daya manusia yang lebih banyak, pengetahuan lebih luas dan update karena secara berkala diadakan training. Selain itu, sistem informasi yang digunakan lebih canggih dan terstruktur karena ada standarstandar khusus yang harus dipenuhi ketika suatu kantor akuntan publik berafiliasi dengan KAP big four. Namun, pada perusahaan yang menjadi sampel dari penelitian ini, perusahaan yang menggunakan jasa dari KAP yang berafiliasi dengan KAP big four tidak selalu mengalami audit delay yang lebih singkat dibandingkan dengan perusahaan yang menggunakan jasa dari KAP yang tidak berafiliasi dengan big four (non-big four). Setiap KAP baik yang berafiliasi dengan big four maupun yang tidak berafiliasi dengan big four akan melaksanakan proses audit sesuai dengan standar dan prosedur yang ditetapkan dalam SPAP SA Seksi 105 (2011), sehingga proses audit yang dilakukan oleh KAP yang berafiliasi dengan big four tidak selalu berjalan lebih cepat yang berdampak pada berkurangnya audit delay. Kesimpulannya, baik KAP big four dan KAP non-big four sama-sama akan berusaha menyelesaikan proses audit tepat waktu. Hal tersebut dibuktikan dengan sampel perusahaan yang menggunakan jasa KAP non-big four yaitu, TBIG pada tahun 2012 mengalami audit delay selama 51 hari, JSMR pada tahun 2014 mengalami audit delay selama 28 hari. Sementara, sampel perusahaan yang menggunakan jasa KAP big four yaitu, ISAT pada tahun 2012 mengalami audit delay selama 119 hari dan CTRA pada tahun 2013 mengalami audit delay selama 83 hari. Hasil penelitian ini sejalan dengan penelitian yang dilakukan oleh Sumartini dan Widhiyani (2014) yang berhasil membuktikan bahwa ukuran KAP tidak memiliki pengaruh terhadap audit delay. Namun, tidak sejalan dengan penelitian Puspitasari dan Sari (2012) yang memperoleh hasil bahwa ukuran KAP memiliki pengaruh terhadap audit delay.

\section{Simpulan, Keterbatasan, dan Saran}

\section{Simpulan}

Simpulan yang diperoleh dari hasil penelitian ini sebagai berikut :

1. $\mathrm{Ha}_{1}$ diterima, artinya ukuran perusahaan berpengaruh terhadap audit delay. Hal ini dapat dilihat melalui hasil nilai t sebesar -4,950 dan tingkat signifikansi sebesar 0,000 atau lebih kecil dari 0,05,

2. $\mathrm{Ha}_{2}$ ditolak, artinya laba rugi operasi perusahaan tidak berpengaruh terhadap audit delay. Hal ini dapat dilihat melalui nilai t sebesar-1,110 dan tingkat signifikansi 0,269 atau lebih besar dari 0,05.

3. Haz ditolak, artinya solvabilitas yang diproksikan dengan rasio Total Debt to Total Asset (TDTA) tidak berpengaruh terhadap audit delay. Hal ini dapat dilihat melalui hasil nilai t sebesar 1,436 dengan tingkat signifikansi sebesar 0,153 atau lebih besar dari 0,05.

4. Ha ditolak, artinya umur perusahaan tidak berpengaruh terhadap audit delay. Hal ini dapat dilihat melalui nilai t sebesar -0,591 dengan tingkat signifikansi sebesar 0,555 atau lebih besar dari 0,05 .

5. Has ditolak, artinya klasifikasi industri tidak berpengaruh terhadap audit delay. Hal ini dapat dilihat melalui nilai t sebesar -0,269 dengan tingkat signifikansi sebesar 0,789 atau lebih besar dari 0,05.

6. $\mathrm{Ha}_{6}$ ditolak, artinya ukuran kantor akuntan publik (KAP) tidak berpengaruh terhadap audit delay. Hal ini dapat dilihat melalui nilai t sebesar 1,039 dengan tingkat signifikansi sebesar 0,301 atau lebih besar dari 0,05.

7. Implikasi dari penelitian ini adalah ukuran perusahaan yang semakin besar akan mengurangi jumlah audit delay yang dialami oleh perusahaan. Oleh karena itu, untuk perusahaan yang dikategorikan sebagai perusahaan kecil diharapkan mampu meningkatkan kontrol internal agar proses audit dapat berjalan dengan lebih lancar. 


\section{Keterbatasan}

Penelitian ini memiliki beberapa keterbatasan sebagai berikut.

1. Variabel ukuran perusahaan, laba rugi operasi, solvabilitas, umur perusahaan, klasifikasi industri, dan ukuran kantor akuntan publik (KAP) hanya mampu menjelaskan audit delay sebesar $23,3 \%$ dan sisanya sebesar $76,7 \%$ dijelaskan oleh variabel lainnya yang tidak terdapat dalam penelitian ini.

2. Perusahaan yang digunakan sebagai sampel hanya perusahaan yang termasuk ke dalam Indeks Kompas 100 periode 2012-2014 sehingga hasil penelitian ini tidak dapat memberi gambaran secara merata untuk setiap sektor industri perusahaan yang terdaftar dalam Bursa Efek Indonesia.

3. Adanya perbedaan antara struktur aset industri finansial dengan industri non-finansial mengakibatkan rentangan jumlah total aset yang dimiliki oleh perusahaan cukup signifikan.

4. Adanya perbedaan atau rentangan yang cukup signifikan pada variabel umur perusahaan.

\section{Saran}

Beberapa saran untuk penelitian selanjutnya sebagai berikut.

1. Penelitian selanjutnya dapat menambahkan variabel independen lain yang kemungkinan dapat lebih menjelaskan audit delay, seperti Return On Aset (ROA), Return On Equity (ROE), opini auditor atau pergantian auditor.

2. Penelitian selanjutnya dapat memperluas objek penelitian ke sektor industri manufaktur yang tergolong lebih luas atau menggunakan seluruh perusahaan yang terdaftar di Bursa Efek Indonesia.

3. Melakukan penelitian secara terpisah terhadap objek penelitian perusahaan finansial dan non-finansial.

4. Pengukuran umur perusahaan yang dihitung sejak tanggal perusahaan pertama kali terdaftar di BEI atau tanggal melakukan Initial Public Offering (IPO).

\section{Referensi}

Aditya, Alfian Nur., Indah Anisyukurlillah. 2014. Faktor-Faktor Yang Berpengaruh Terhadap Audit Delay. Accounting Analysis Journal. Vol.3, No. 3, Juni 2014, hlm 334-342.

Agoes, Sukrisno. 2012. Auditing : Petunjuk Praktis Pemeriksaan Akuntan oleh Akuntan Publik. Jakarta : Salemba Empat.

Almilia, Luciana S., dan Lucas Setiady. 2006. Faktor-faktor yang Mempengaruhi Penyelesaian Laporan Keuangan pada Perusahaan yang Terdaftar di BEJ. Seminar Nasional Good Corporate Governance di Univ. Trisakti (November).

Arens, A. A., R. J. Elder, dan M.S. Beasly. 2014. Auditing and Assurance Services (Fifteenth Edition). England: Pearson Education Limited.

Ariyani, Ni Nyoman T. D., dan I Ketut Budiartha. 2014. Pengaruh Profitabilitas, Ukuran Perusahaan, Kompleksitas Operasi Perusahaan, dan Reputasi KAP Terhadap Audit Report Lag Pada Perusahaan Manufaktur. E-jurnal Akuntansi Universitas Udayana, Vol. 8, No. 2, hlm. 217-230. 
Arungningrum, S., dan Made Gede Wirakusuma. 2013. Pengaruh Profitabilitas, Leverage, Kompleksitas Operasi, Reputasi KAP, dan Komite Audit pada Audit Delay. E-jurnal Akuntansi Universitas S.2, 251-270.

Ayemere, Ibadin L., and Afensimi Elijah. 2015. Corporate Attributes and Audit Delay in Emerging Markets : Empirical Evidence from Nigeria. International Journal of Business and Social Research. Vol. 05, Issue 03, 2015.

Bank Indonesia. 2008. Undang-Undang Republik Indonesia Nomor 20 tentang Usaha Mikro, Kecil, dan Menengah.

Ervilah, dan Nurul Fachriyah. 2012. Faktor-Faktor Yang Mempengaruhi Audit Delay. Jurnal Akuntansi : Universitas Brawijaya.

Eka, Kristianti. 2014. Pengaruh Total Asset, ROA, DER, Ukuran KAP, dan Laba atau Rugi Perusahaan Terhadap Audit Delay Pada Perusahaan Manufaktur Yang Terdaftar di Bursa Efek Indonesia Periode 2011-2012. Jurnal Economic \& Business Research Festival.

Febrianty. 2011. Faktor-Faktor yang Berpengaruh Terhadap Audit Delay Perusahaan Sektor Perdagangan yang Terdaftar di BEI Periode 2007-2009. Jurnal Ekonomi dan Informasi Akuntansi (JENIUS). Vol. 1 No. 3.

Ghozali, Imam. 2013. Aplikasi Analisis Multivariate dengan Program IBM SPSS 21 Update PLS Regresi. Semarang : Badan Penerbit Undip.

Griffin, Ricky W. 2013. Management : Principles and practices, 11th edition. Amerika : SouthWestern.

Himayati. 2008. Eksplorasi Zahir Accounting. Jakarta : PT Elex Media Komputindo.

Horngren, C.T., Srikant M.D., Madhav V.R. 2015. Cost Accounting : A managerial emphasis 15th edition. England : Pearson.

Ikatan Akuntan Indonesia. 2014. Pernyataan Standar Akuntansi Keuangan. Jakarta : Ikatan Akuntan Indonesia

Institut Akuntan Publik Indonesia. 2013. Standar Profesional Akuntan Publik. Jakarta : Salemba Empat.

Indonesia Stock Exchange, 2015, website : $\underline{\text { http://idx.co.id/ }}$

Indriyani, Rosmawati Endang., dan Supriyati. 2012. Faktor-Faktor Yang Mempengaruhi Audit Report Lag Perusahaan Manufaktur di Indonesia \& Malaysia. The Accounting Indonesian Review Vol. 2 No. 2. Page 185-202.

Iskandar, Meylisa J., dan Estralita Trisnawati. 2010. Faktor-Faktor yang Mempengaruhi Audit Report Lag Pada Perusahaan yang Terdaftar di Bursa Efek Indonesia. Jurnal Bisnis dan Akuntansi. Vol. 12, No. 3, hlm 175-186. 
Kartika. 2011. Faktor-Faktor yang Mempengaruhi Audit Delay Pada Perusahaan Manufaktur yang Terdaftar di BEI. Dinamika Keuangan dan Perbankan, November 2011. Vol. 3 No. 2.

Kartikahadi, H., dkk. 2012. Akuntansi Keuangan berdasarkan SAK berbasis IFRS. Jakarta : Salemba Empat

Laksono, Firman Dwi. 2014. Faktor-Faktor yang Mempengaruhi Audit Delay dan Waktu Publikasi Laporan Keuangan. Diponegoro Journal of Accounting, Vol 3, No. 1, hlm. $1-13$.

Lianto, N., dan Budi Hartono Kusuma. 2010. Faktor-Faktor yang Berpengaruh Terhadap Audit Report Lag. Jurnal Bisnis dan Akuntansi, Vol. 12. No.2, hlm. 97-106.

Martia, Dina Y., \& Ulfah Hidayati. 2013. Faktor-Faktor yang Mempengaruhi Audit Delay Pada Perusahaan Lembaga Keuangan. Jurnal Sistem Informasi Manajemen dan Akuntansi SIMAKS), Vol. 2, No. 06, hlm. 21-35.

Modugu, Prince K., Emmanuel Eragbhe, dan Ohiorenuan Jude Ikhatua. 2012. Determinants of Audit Delay in Nigerian Companies : Empirical Evidence. Research Journal of Finance and Accounting. Vol 3. No. 6.

Nuh, Muhammad dan Suhajar Wiyoto. 2011. Accounting Principles (Suatu Aplikasi Perusahaan Indonesia Berbasis PSAK \& IFRS). Jakarta : CV Lentera Ilmu.

Otoritas Jasa Keuangan, 2015. website : http://www.ojk.go.id/

Petronila, Thio Anastasia. 2007. Analisis Skala Perusahaan, Opini Audit, dan Umur Perusahaan Atas Audit Delay. Jurnal Akuntabilitas Vol 6, hlm 129-141.

Puspitasari, E., dan Anggraeni Nurmala Sari. 2012. Pengaruh Karakteristik Perusahaan Terhadap Lamanya Waktu Penyelesaian Audit (Audit Delay) Pada Perusahaan Manufaktur yang Terdaftar di Bursa Efek Indonesia. Jurnal Akuntansi \& Auditing, Vol. 9, No.1, hlm. 31-42.

Sahdana, Rizki Agung. 2011. Faktor-Faktor Yang Mempengaruhi Audit Delay. Skripsi Fakultas Ekonomi Universitas Jember (UNEJ) : tidak diterbitkan.

Sari, Indah P., R.Adri S., Drs. Elfi Ilham. 2014. Pengaruh Ukuran Perusahaan, Solvabilitas, Dan Reputasi KAP Terhadap Audit Delay Pada Perusahaan Property \& Real Estate Di Bursa Efek Indonesia Periode 2009-2012. JOM FEKON Vol. 1, No. 2, Oktober 2014.

Saputri, Oviek D. dan Etna Nur Afri Yuyetta. 2012. Analisis Faktor-Faktor Yang Mempengaruhi Audit Delay (Studi Empiris Pada Perusahaan Yang Terdaftar di Bursa Efek Indonesia. Fakultas Ekonomi. Universitas Diponegoro.

Sarwono, Jonathan. 2012. Metode Riset Skripsi Pendekatan Kuantitatif : Menggunakan Prosedur SPSS. Jakarta : Elex Media Komputindo. 
Sekaran, Uma dan Roger Bougie. 2013. Research Methods for Business. USA : John Wiley \& Sons.

Shulthoni, M. 2013. Determinan Audit Delay dan Pengaruhnya Terhadap Reaksi Investor. Jurnal Akuntansi Aktual, Vol. 2, No. 1, hlm 9-18.

Subramanyam, K.R., dkk. 2014. Financial Statement Analysis 11th edition. New York: McGraw-Hill.

Sugiarto, dkk. 2011. Audit Delay Related Variables dan Company Related Variables yang Berkaitan Audit Delay dan Dampaknya Terhadap Return Saham PerusahaanPerusahaan yang Go Public di BEI. Jurnal Akuntansi. Vol. XV No.3, hlm 291-308.

Sumartini, Ni Komang Ari, \& Ni Luh Sari Widhiyani. 2014. Pengaruh Opini Audit, Solvabilitas, Ukuran KAP, dan Laba Rugi Pada Audit Report Lag. E-Jurnal Akuntansi Universitas Udayana.

Sunyoto, Danang. 2013. Metodologi Penelitian Akuntansi. Bandung : Refika.

Togasima, Christian Noverta, \& Yulius Jogi Christian. 2014. Analisis Faktor-Faktor Yang Mempengaruhi Audit Report Lag Pada Perusahaan Yang Terdaftar di Bursa Efek Indonesia Pada Tahun 2012. Business Accounting Review, Vol. 8, No. 2, Juli 2014, hlm. 151-159.

Tuanakotta, Theodorus M. 2011. Berpikir Kritis dalam Auditing. Jakarta : Salemba Empat.

Weygandt, Jerry J., Paul D. Kimmel, Donald E. Kieso. 2013. Financial Accounting, IFRS Edition 2e. USA : John Wiley \& Sons.

Kieso, Donald E., Jerry J.W., Terry D.W.. 2013. Intermediate Accounting $2^{\text {nd }}$ edition, IFRS Edition 2e. USA : John Wiley \& Sons.

Whittington,O. Ray dan Kurt Pany. 2015. Principles of Auditing and Other Assurance Services, 20th Edition. New York : Mc-Graw-Hill.

Yulianti, Ani. 2010. Faktor-Faktor Yang berpengaruh Terhadap Audit Delay. Skripsi. Universitas negeri Yogyakarta.

www.kompasiana.com

www.neraca.co.id

www.sahamok.com 